This article was downloaded by: [New York University] On: 13 August 2013, At: 12:35

Publisher: Routledge

Informa Ltd Registered in England and Wales Registered Number: 1072954 Registered office: Mortimer House, 37-41 Mortimer Street, London W1T 3J H, UK

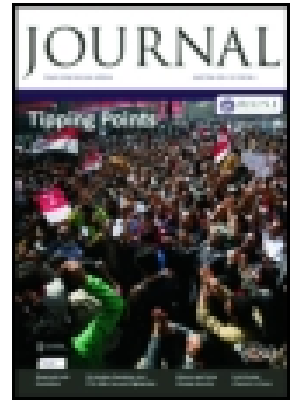

Royal United Services Institution. J ournal

Publication details, including instructions for authors and subscription information: http:// www. tandfonline.com/loi/ rusi19

\title{
On the Employment of the Reserve Forces in Case of an Expeditionary Force Being Sent Abroad
} Colonel H. C. Fletcher C.M.G. Published online: 11 Sep 2009.

To cite this article: Colonel H. C. Fletcher C.M.G. (1878) On the Employment of the Reserve Forces in Case of an Expeditionary Force Being Sent Abroad, Royal United Services Institution. J ournal, 22:95, 350-368, DOI: 10.1080/03071847809416643

To link to this article: http://

dx. doi.org/ 10.1080/03071847809416643

PLEASE SCROLL DOWN FOR ARTICLE

Taylor \& Francis makes every effort to ensure the accuracy of all the information (the "Content") contained in the publications on our platform. However, Taylor \& Francis, our agents, and our licensors make no representations or 
warranties whatsoever as to the accuracy, completeness, or suitability for any purpose of the Content. Any opinions and views expressed in this publication are the opinions and views of the authors, and are not the views of or endorsed by Taylor \& Francis. The accuracy of the Content should not be relied upon and should be independently verified with primary sources of information. Taylor and Francis shall not be liable for any losses, actions, claims, proceedings, demands, costs, expenses, damages, and other liabilities whatsoever or howsoever caused arising directly or indirectly in connection with, in relation to or arising out of the use of the Content.

This article may be used for research, teaching, and private study purposes. Any substantial or systematic reproduction, redistribution, reselling, loan, sub-licensing, systematic supply, or distribution in any form to anyone is expressly forbidden. Terms \& Conditions of access and use can be found at http://www.tandfonline.com/page/terms-andconditions 


\section{LECTURE}

Fridas March $29 \mathrm{th}, 1878$.

Iiedt.-General T. MI. SCOTT MICMIURDO, C.B., in $t$.

ON THE FMIPLOYAIENT OF THE RESERVE FORCES
OF AN EXPEDITIONARY FORCE BEING SENT $A$

By Colonel H. C. Fuetcher, C.Ar.G., Commanding 2ni Scots Guards.

'THERE is a well-known proverb, qui s'ercuse s'accuse, and a' having it applied to myself, I must preface this paper by si can put forward little that is new, or that has not. been considered by those whose duty it is to make the neccssa tions for war, on paper, if not in a more practical manne: relates to the defence of Great Britain, has been dealt wit] books and pamphlets and formularised into plans more or $\mathrm{l}$ and little remains for me except to lay before you a digr people's thoughts, and to endearour to present a picture of affairs that would arise if England were engaged in serions

Let us therefore endearour to realise the condition of $t$ soon after war had been declared with a powerful European for the sake of argument and withont prejndice let us st nation to be Russia. Tro army corps, comprising the n regular forces of England and Ireland, excepting the skelet. battalions, including six battalions of Guards, and a regime Household Caralry, and made up of the Army reserre, portion of what is called the Militia reserve, have left for the ] are 10,000 men on their way from Canada, and the adrance force of 80,000 native Indian tooops are passing through the The conntry is denuded of regular troops, and theirordinary $r$ as the task of providing reinforcements, is falling on the $\mathrm{Re}$ and on those who are left in charge of the various districts in country has been divided. Little or no analogy can be de what was done during the Crimean war. At that time we $d$ state of hostilities after a long peace, with but little or : 
iion, and without recognising the latent power which possessing the population and realth of England, can Toe fought our battles with a small body of regular troops, directly by the Militia, who garrisoned the fortresses in the nean, maintained a respectable armed force at home, and whe worked nobly and unselfishly in providing recruits to repair of the regular troops. As the war went on we had recuurs and expedients which I scarcely think creditable to a grea We sent to Germany, Switzerland, and Italy to hire $\mathrm{m}$ whilst we neglected to utilize the large and I may say warli tion of our own Isles, not apparently imagining that soldier procured by other methods than those which obtained $d$ wars in Spain and in America. In thus acting we, low followed former precedents. Indeed, to quoto from "Clode "Forces of the Crown," no Continental war was ever previon on with so small a number of foreign tronps. "The iden seer been that armies. were to be recruited solely from the lower cl: soldiers should be purchased in the cheapest market, and-pro reached to a fixed and certainly not high standard of physical. that it was a matter of indifference whether they were fighting in which they were interested, or merely for their pay. Hapl the brunt of the struggle fell on our own brave national ti notwithstanding the many disadvantages under which they owing to the neglect of the Army by the nation during the followed the fall of Napoleon, they manfully upheld the renown, and brought us out of difficulties that it woulc unwise to incur again.

The ideas of the scale on which war can be conducted hav since the Crimean days. Nations have learnt that by proper tion, and by the use of the many mechanical means $w$ century has produced, armies of a sjze unknown in former Eu tory can be brought rapidly from distant points to the scene: tion, and can be maintained with little reference to the sease year, or to the resourees of the conntry which may be the the: crnpaign. War is no longer the affair of the upper classes and of the lower as soldiers-all ranks and all conditions part in it, whether forced to do so by the iron rule of conse propelled by the influences that free countries like Eng America should know how to exert when a great nationa stirs to the depths the patriotic feclings of the citizens. If to imitate the practice of continental nations, we may st: lesson from the gigantic efforts made by the Northern and States during the Civil War of $A$ mericn, and wo may gather frc of those campaigns, examples, or rather warnings, of the ne realizing at the commencement of a struggle the efforts rec conducting it to its ultimate end, and the losses in men, mi honour, that will flow from neglecting to put forth the nations at the outset of a war.

Before proceeding further, it will be well to come to son standing as to the land forces on which England would hav voL. XXII. 
We have at home, according to returns based on the Arn

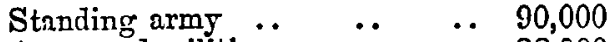

$$
\begin{aligned}
& \text { Army and militia reserves } \quad \text {.. } 38,000 \\
& \begin{array}{llllll}
\text { Nilitia } & \text {. } & \text {. } & \text {. } & \text {.. } & 85,000
\end{array} \\
& \text { Effective rolunteers } \quad . . \quad \ldots 180,000 \\
& \text { Second class army reserves } \quad . . \quad 23,500 \\
& \begin{array}{lllll}
\text { Yeomanry.. } & \text {.. } & \text {.. } & \text {.. } & 10,000
\end{array} \\
& \text { Total .. 426,500 }
\end{aligned}
$$

And we learn from Mr. Gathorne Hardy in his speech on Army estimates that he looks upon 400,000 men as the military establishment. It will, therefore, bo allowable t figures as representing approximately the home forces wi should commence war. In India wo have $63,000 \mathrm{E}$ 120,000 native troops, besides contingents, which (pa independent Princes) might be attracted to our service also the resources of our great colonies, who, if England committed to war, would not be content to be mero look struggle of the parent State. From Canada re might; I br on 10,000 infantry, a regiment of cavalry, and two batterit and at least a company of engineers, as a first instalmen own warlike population, supplemented by the many rest] English birth from the adjoining great Republic, would es if they did not increase.

As the actual commencement of hostile operations on depend on us, and as even the theatre of the campaign open to our solection, the strength, composition, and tin abroad an expeditionary force would in great measure be England's preparation for war. Efforts are now being ready for the field two army corps of 74,000 Office To do this, thirty-nine battalions of the Line, and three o would hare to be sent, and these battalions, after 1 of jouths who have not completed eight months' st require, to bring them up to war strength, abe thousand five hundred $(18,500)$ men, who would have from the Army reserves, the Militia reserves, and from the of Guards and Line who would still renain after the dep two corps. These homo battalions would consequentl attenuated in numbers, even although they had receiv ranks the younger soldiers of the war battalions. There plete them, 23,000 men wonld be required, whilst, to brin Irilitia battalions to war strength, 50,700 would have to $\mathrm{k}$ all, without counting India and the Colonies, nearly 74 recruits and 4,000 cavalry and artillery recrnits would found with as little delay as possible. But these nur represent the strain that would on the ontbreak of hostilit immediately on the population. The losses of war wou met, and our Indian Army supplied. For the former $7 \mathrm{E}$ 
the number in the field is considered to be a fair annual pri therefore to maintain in the field $60,000 \mathrm{men}$, an annual si 45,000 becomes requisite, whilst the average number for India Colonies would be 8,000 . Considerably more than 100,000 would therefore have to be obtained in the first jear, in order plete and keep up two corps d'armée, and to maintain the (which would be the reserve as well as the training school of tl in the field), and to afford the ordinary drafts to India and the 1 We must therefore imagine our quiet and somerrhat sleepy depots in full working order, recruits constantly pouring $i$ provided with arms, clothing, and accoutrements, and then $p$ to the affiliated Militia battalions, who would probably occ barracks and quarters of the absent troops of the Line. Alder great training school of the country, would afford permanent a dation for a large number, whilst during the summer months a troops would be placed under canvas. Other stations would be for camps of instruction, their localities being fixed in great with reference to the enemy with whom we might be engaged. appeared any possibility of invasion, our Southern and Eastern would necessarily monopolize the larger portion of our home A the conveniences of localities for training local troops would give way to the general scheme of defence.

The memorandum on Mobilization drawn up for the Gor divides the home Army into six corps for England, une for Ire one for Scotland; four of these corps being allotted to the counties of England. These corps comprise regular troops, Volunteers, and Pensionors, who would be stationed in pr camps, in our fortresses, and in the case of the coast rolu. near as possible to the localities to which they belong; whils entrenched camp near London wonld probably be the head station of the Metropolitan forces.? If the war were between and an enemy not possessed of naval power, the necessities of $p$ from invasion might give way to the adrantages of locali forces. The loss of labour consequent on the withdrawal of men from their ordinary pursuits would entail much inconv and if military training could be so arranged as to permit o: proportion of the force being on leare during the seasons of when agricultural labour is most required, considerable snvir waste of the wealth of the country might be effected. In way with the Volunteers.' The embodiment of portions of $i$ would be necessary, not only that garrison duties should be carried on, but for purposes of discipline, as men must be together somewhat permanently under their Officers and non sioned officers in order to acquire the cohesion requisite for a force.

Arrangements might duubtless bo made for the garrison $d v$

1 The mobilization acheme provides for the full employment of the Tolu In addition to the garrisons which would hare to be furnished for tl places, the coast rolunteers organized into brigades would oppose the euc landing, falling back on the positions selected for defence. 
performed week about by certain regiments or companies of as it is most important that the young troops who are bein: rcinforcements for the Army in the field should not waste and injure their health by performing the routine of what sentry go. They require their days for military exercises, $f$ shooting, for ontpost duties, and for instruction in the vari ments of a soldier on service; and, consequently, they must from garrison duty, and not be expected to bo trained, like for the Guards' regiments, during the Crimean War, in th great city and with three aights in bed. The rolunteers o and of our garrison towns might be most useful in affordin to the young soldiers of the regular Army and of the Mrilitia to the drill and exercises which those not on duty migh daily by a proper distribution of time. For it must be 1 that a serious war will change ideas in regard to relaxatior amusement rill have to gire way to the relief which an $\mathrm{a}$ work affords. Many of our clerks, shopkeepers, and citizens an hour daily after the termination of their ordinary work, $i$ of training were sufficiently near; whilst a well organize Sunday parades would not only give fifty-two additional d Jear, but would often tend to the better keeping of the day

Thus, whilst our garrisons in the Mediterranean are Militia to be fed from their depôts; whilst onr fortified pla have also received Militia and local Voluntecrs in place of reg whilst large camps have béen established at convenient pla receipt of recruits from the brigade depots, and for the bet of temporarily embodied regiments of Volunteers, cvery $\mathbf{~}$ be taken to find places and to arrange time so that the $V$ the great cities should have the advantage of drill pari pasi regular work. It will be in the recollection of many $\mathrm{N}$ living, that the fear of invasion at the commencement of century gare rise to a similar state of affairs. Then the $\mathrm{g}$ : tile establishments raised, trained, and officered companies of Men did their work in life like the Jews described in 1 Judges, with their renpons ready at hand. Besides Mrilitia permanently embodied, and which possessed the qualitie: troops, there were in England alone, in 1805, 350,000 Volv prising cavalry, artillery, and infantry. These were regul: on by the Generals of the districts, and on the whole their very farourable-_" fit to take their place with troops of the the usual observation in the columns of remarks.

It will not be out of place if we glance at the rork $p$ what are now termed the Reserve forces, during the close of the commencement of the present century. To quote $f_{1}$ "Reserve Forces," out of 80,620 militiamen, in the year volunteered to serve under Sir Ralph Abercrombie, and s wards 10,414 joined the regular Army. In 1808, 30,88 obtained for the Army from the Militia, whilst in 1813, the men of the Militia were allowed to volunteer into the Arm us Militia with the Army abroad, the battalions and $r$ 
Militia being under their own field officers. In 1800 , as $\mathrm{mr}$ is said to have been paid at Plymouth for a substitute, whils went on condition of receiving four shillings a day, and an himself for seven and threepence a pound. A general Milit passed in 1802, by which men between the ages of 18 and be raised by ballot, and to pay a fine of $10 l$. to be exemp years. In 1808, a local militia was raised, and 214,000 obtained by ballot, no substitutes being allowed. During the 1 War, besides furnishing Officers and men to the Army, the Mil qua militia in Portagal, whilst they sent large quotas to the fought at Waterloo. At the time of the Crimean War, $t$ furnished from 25,000 to 30,000 men for the line, whilst 50 , representing nearly 41,000 men, volunteered for foreign servi these ten regiments were selected to serve at Mlediterraneal during the Indian Mutiny also, 18 regiments offered them service abroad.

In addition to the Militia, large numbers of volunteers w under the Defence Act of 1802 , which was subsequently anen Lovy en Masse Act, when 420,000 men voluntecired partly the ballot for the Militia. In 1804 and in the four subsequ the number of volunteers in Great Britain areraged abou Ireland furnishing 70,000. A portion of this force received 1806 , after which date, arms only were issued, as it was found who ought to have been serving in the regular Army or the $A$ enrolled themselves in the Volunteers. It is difficult to the exact numbers, as they of conrse varied from year To quote from statistics compiled by General T. B. from records in the Quartermaster-General's office, anc under the notice of this Institution in his admirable pape "Another Warning Voice from 1805," it appears that in I 1803 , there were 327,286 rolunteers under arms, whilst later (and the numbers were probably nearly the same in 1803) there was a force of 9,622 regular artiller: cavalry, 47,116 infantry, 56,316 militia, making a total o regulars and militia, or a grand total of uprards o men under arms in Great Britain alone, of whick the popnl less than half what it is at the present time. I mention thes as giving an iden of what this country can do under the pre serious crisis and of a great war, although I cannot help agre Mr. Burke, who, denouncing this timid policy, says, "Who w "credited that 200,000 men were kept in England and 80,000 for the mere purpose of an inert and passive defence, and $t$ very constitution the greater part of this force was disa defending us against the enemy by one preventive stroke hostility?"

It is partly with the view of directing attention, not $o$ : effort this country is capable of, bat also to the blot in a sys keeps so large a portion of the Army, from fighting beyond 1 of Great Britain, that I have brought the subject of the eI of the Reserve forces ander sour notice. 
There is no more false economy than that of stinting milite tions at the commencement of war, or of failing thoroughly nise the gravity of the occasion and the necessity of sacrifi conceived notions and individual interests to a mighty and effort.

In well ordered and systematically governed countries it a difficult matter to induce departments to take broad accustomed views of subjects, the details of which engr daily attention. The very excellence of the organization of ment Departments, and the rery zeal of the emplojés, may ev from their ability to meet an unexpected strain. There is a to lose sight of great objects and to work for narrow air of for the general good. The heads of departments are free from prejudices, and are anxious to push the coacl those who grease the wheels do not work heartily with repair the harness, whilst the road makers, intent on the exc their roads, cannot bo indnced to preparo rough-and-ready $t$ temporary and exceptional use. In England there are resources for war, but these resources cannot be utilizer changes in the organization of our military establishments, doubtless suited for dealing with the frequent small wars England is engaged, but which require elasticity to meet a $\mathrm{g}$ Napoleon's system, which in the height of his career he certai too far, of refusing to recognise any difficulties, and req subordinates to carry out his plans without putting forward . has many merits, and might be copied with advantage in the tration of our military affairs. Boldness - is essential not o conduct of armies in the freld, but in the adoption of plans change, and a departure from the accustomed grooves.

I hope, horrever, that if war break out, we should fully position and that the end of the first month would see En verted into a great camp, secruits pouring into the depôts, instruction in full swing, and the rolunteer regiments, $v$ standards of efficiency than at present, taking their tr regular militury duties of the towns and garrisons, and large quotas in rotation for periodical training at the camps. those who had left their ranks would rojoin the several which they previously belonged, and active and energe Officers of the Army would offer their services as instruc additional battalions and companies that would specdily The Yeomanry-converted in most instances into mounted would give an outlet to the military instinct of the farmers, no mean reserve to the cavalry, whilst it would be for impossible to check the formation of field batteries, $\mathrm{w}$ ? confident might bo sufficiently trained to act with infan event of an invasion. The strain on society would at fir great, bat gradually we should accommodate ourselves 1 condition of affairs, and would be able to show foreign $G$, an example of the latent energy possessed by a free cou principal difficulty would be that of discorering the best 
raising the number of men to fill the ranks of the regim Line, and of the embodied Militia. If the countrs conld be acknowledge the necessity of a modified conscription, $t$ recruiting would be greatly diminished. Once get the $\mathrm{m}$ seription into the Militia, and the Line conld easily be fer source, whilst, as has been pointed out by Lord Elcho and standard of efficiency of the Voluntecrs, supposing them to from the ballot, might bo considerably raised. Merely inducements, whether given in the shape of pas, pension, of would be a hard matter to raise the requisite numbers.

States nearly succeeded in doing so, but towards the close a man was worth $£ 200$; and the demoralization and abuses on the offer of high bounties are so lamentable that almosi would be preferable to such a method of procuring recruil be impossible to face this difficulty until the nation and the $\mathrm{C}$ are brought face to fnce with it, but no pains should be sr preparation of some scheme that could readily and quicl into operation. If high bounties be once giren, or if th expected, it will be a hard matter to withdraw this bribe 1 who would benefit by them, and a check to recruiting occasioned at the vers time men were required. Far better a of hostilities to place the whole matter fairly before the cou: put in force the law now in abeyance of ballot for the Militi

To return to the subject of the Reservo forces: it wil have been observed, that throughout this paper the desI expeditionary force of only two army corps has been co: whereas England, with her population and. wealth, or able to keep in the ficld more than double that numl analogy is to be furnished from the efforts made by other believe it would be impossible as war went on, and as men the work, to check the enthusiasm of the Reserve fo would not be content to see their comrades of the line eng: field, and they themselves kept in garrison and in camp. Crimean War, the regiments of militia at Corfu and Malta willingly voluntecred to join the army before Sebastopol. now, when military knowledge and military feeling have throughout the country, and when all classes, eren in peace-1 bear a portion of the burden which soldiering entails. It that these regiments could send recruits to the Line; dor would do so; but if their services were accepted as regiment numbers would volunteer; and if universal conscription is tc every channel must be thrown open by which troops are cured. Doubtless there are difficulties to be overcome an to be rooted up; but it would be a bitter satire on free in it were said that England would not bear the burden of c or show sufficient intelligence to adapt existing regulations abnormal condition of affairs. In the same way, the rol form the ontlet for the military energies of our middle cl: to have opportunities given them for service before the en motto is, "Defence, not Defiance;" but Heaven forbid tl 
should erer wage wars of defiance; she merely fights to $d$, possessions, although to do so she must fight beyond the seas

It is said that several regiments have already placed their s the disposal of the Secretary of State for War, and it would be possiblo to raiso from the effective volunteers a considera and one which any Officer would be proud to command. A might arise in maintaining it without trenching on the ? grounds of the Army and the Militia; but if there were cos for the Iatter, with indncements to enter the regular Arm: excmption only in farour of efficient volunteers, the latter mi tain as well as furnish a representative force in the field.

As the war went on, much that appears now to be complica disappear, and a sjstem once organized would either simplify develop its impracticability. In the meantime, a force form present efficient volanteers, and well officered, would not only siderably to the strength of onr army, but wonld be of politic tance as evincing the carnestness of the people, and the rea classes not usually found in the ranks of the English Arm: their part in the dangers of war.

A clear recognition of the distinct duties of the Reser might prevent mistaken ideas, and lend to a simplification 'I'heir first duty, as has been pointed ont, is to provide for forcement of the troops in the ficld. From this, the rolu volunteers, will be exempt, unless they were prepared to do representative force, and act with the army abroad. The sec of the reservo forces, is to be in readiness to take their pla field in the event of additional corps d'armée being required, depôts must be provided for them, as well as for the reguli 'The system would remain the same, viz., reoruits for the for field joining at the several depôts, and being transferred fr depôts to the camps of instruction, previous to their embal service abroad; the work of garrisoning England would exclasively on the troops retained permanently for home and provided from the classes who could not deroto their wh to military work.

Thus the advice given by Mr. Pitt in his speech in Parlia the Volunteer Act of 1803 would be followed :- "I was forme Mr. Pitt, "and still am, of opinion that to a regular arn " however superior, however excellent, even aided by the $\mathrm{m}$ " ought not solely to trust, but that in a moment so erentful, in

" so siugrular in its character, and which perlinps may be tedi "duration, we ought to superadd to the regular army some pr " system of national defence, either to a certain degree compr

" formed upon the voluntary zeal and patriotism of the count

"This onght to be resorted to as the grand source of domestic

"The army must be the rallying point; the army must furnish

" must afford instruction, must gire the principles on which the

" system of defence must be formed, and by which the volunteer

"the cuuntry, though, in a military view, inferior to the regul

" would, fighting on their own soil, for everything dear to int

"and important to the State, be invincible." 
There is still another duty which, though perhaps not directly within the scope of this paper, has so near a relatio efficiency of an army raised from the body of the populatic may be excused from alluding to it. If our Army and Militi: men (unny of them boing married) were called into the the militia were to furnish large drafts to fill up the gaps of . if the rolunteers contribnte their quota, there must, owing tc valence of early marriages, be a very considerable number c and children deprived of their natural supporters, and reducer straits for a livelihood. It is a grierous thing for a fightin think that lis wife and little ones are in penury and want. militate greatly against voluntary enlistment if men felt $t$ absence would entail privations on their families, whilst $\varepsilon$ equal evil would be occasioned if indiscriminate charity werc on those who were left at home. There is, therefore, a rast organization and for systematic preparation, if the best $\mathbf{r}$ assisting the wives and families of the men who would fight th battles is to be arranged, and if the opposite evils of negler unwise benevolence are to be avoided. Doubtless, much of now performed by men might, withont undue tax on their fall on the weaker sex, and it would be the duty of emplozers to endeavour to discover how this arrangement conld best be but still there would be plenty of scope for charity, and a wic which those who do not actually fight the battles of the cor still labour to contribute to the national weal. ${ }^{1}$

In more than one way must the patriotism of the $\mathrm{cm}$ ] labour be appealed to. If conscription is to be avoided, ir well as direct encouragement will have to be given to recruiti Army (and in this word I include the Reserve force). I present, must some of our principal railiways refuse to tak men, for fear lest they should be called on in case of any emergency. The education and tmining of soldiers ought pessport to many of the situations where habits of order and are essential. The railways, the police, the county constabul the warderships of prisons wonld furnish emplojment for larc of men who have completed their three or six Jears in the ra in the erent of serious war, their places could, after a little many instances be filled by those whom wounds and sickn hare incapacitated for active field service, and who would ye for less arduous work. Some sacrifices would doubtless $h$ made, the luxury of perfectly performed work, and of a supera of labour might have to be foregone, and the public would ha with deficiencies which a great national war necessarily entails.

1 An announcement has just been macle of the intention of the Gorern out the Army and Militia Reserres. 'The dilliculty, therefore, of dealin wires and families of those who have to join the ranks should at once be erils of affording them parish relief are so obrious that they do: enumerating, but there are other ways in which assistance can be giren, equally with justice, points to the necessity of at once meeting the differ alleriating the distress which the withdrawal from their familios of so ma and parents must necessarily cause. 
one who trarelled through the Confederate States during War, numerous instances will occur of the absence of the $\mathrm{a}$ : of labour, and of the inconreniences ensuing from such a $c$ affairs, which were cheerfully borne by a people earnest ir to which they were committed.

I have endeavoured in this short paper not so much to lay definite duties for the Reserve forces, as to point out how bo expected from them if England were to be drawn into great Power. A prevalent idea among many persons apt that,-secure in their island, - they will be able to look on which the regular army, assisted perhaps by a fer of the of the regiments of the Rcserve vill take part, and that, bey an increased income-tax, they will have little personally to or to suffer from it. To the majority of Englishmen this w: in which the Crimean War presented itself. There was little to mark that England was engaged in an important str sentries on the palaces and public buildings were perhaps rat and younger, and if anyone took the trouble of going to he would have seen a large force of embodied militia, and at some German mercenaries, but the ordinary life of the Eng was not disturbed; everything went on as usual, and few putting themselves eren to inconvenience to assist in $t$ tion of a war, waged far from our own shores, and not dirc ing every-day routine. But if the cloud which is now she over the European horizon bursts in storm, the work that? will have to do will tax all their energies. It is a good sig in the Regulars, the Militia, and the Volunteers, recrniting $j$ the reality of active service presents itself. - It is encoura the increased efforts which are being made by the roluntee? to raise their standard of efficiency, not only in what may oye, but in real essentials which even the regular trool beginning to recognise. The provision of regimental tra the best method of using it, together with the formation of corps, are attracting the attention of many of ou: regiments, whilst the fact alludea to by $\mathrm{Mr}$. Hardy of of annual encampments is a proof of the zeal with that tends to the best method of military training is tal practised. So far so good, but more will probably be reqr necessity for conscription may have to be faced, and the c hare to show that the sneer against our young men from $t$ from Manchester imputed to Prince Bismarck has no foul that trae civilization does not lead to effeminacy or to a dangerous duties. The thought of fighting our battles 1 extraneous aid, except merely as supplementary to the Nat ought to be put aside. How can we ask Canada for help, avail ourselves of our own Reserve forces? Is it consister dignity, or even with the safety of our Indian Empire Asiatics, when Anglo-Saxons sit at homo at ease reading spiced narratives of newspaper war correspondents? We m own battles, or fall as every empire has fallen that evadt the belief that gold can be a substitute for iron. 
Lord Bacon, in his essay on the True Greatness of Kin States, gives the following connsel: "Walled towns, stored ar " armories, goodly races of horse chariots of war, elephants " artillery and the like-all this is like a sheep in a lion's s. " the breed and disposition of the peoplo be stout and war] " number itself in armies importeth not much where the pe "weak courage." Therefore, he continues, "let any Princ "think soberly of his forces, except the militia of natives be " valiant soldiers; and let Princes on their side, that hare "martial dispositions, know their own strength, unless thej "otherwise wanting in themselres. As for mercenary for "amples show that, whatsoever Estate or Prince doth rest up " may spread his feathers for a time, but he will mew them s I should like to concludo this paper with one practical s If a volunteer brigade could be raised for service in the fiel be well for those who would comprise it to place their serv disposal of the Government for the forthcoming summer would then be seen of what good stuff such a body of composed, whilst a fortnight's peace campaigning, and the with the staff under whom they would act, and with alongside of whom they would serve and fight, would wor in welding the heterogeneous elements of which such a bris necessarily be composed, into a concrete and solid mass duty to which it might be put.

In foreign countries the impulse of action has to come fre in England and America it is the peoplo who push on the Gr and therefore at the present crisis, when war and peace are in the balance, there is an opportunity for our Reserve forc those who command them, to systematize schemes of improven to organize plans for, the employment of the vast latent por which England possesses, and which she ought to be able to ntilize.

Colonel Lord WATExEr, F.R.S.: I riso to address this meeting at this the discussion on a special grouud. It was my fortune to hear yesterds the assembled Legislature of England the necessity of placing the Reserre arms, an erent which probably will be one of the most remarkable of of this century; and I find to day by an extraordinary coincidence to gallant friend the lecturer has giren us an insight into what the use of $t$ Forces may be. In both cases there is an identity that is gratifying who respects the sclf-restraint of the English people. The announce Legislature was receired in respectful silence, but certainly with refc enormous results that might be the consequenco; and when we had it and as $I$ will in a few words show, for an excellent purpose, what has $b_{1}$ the Reserre Force, that announcement was also receired with the si who are not carried away by sudden floods of impulse or sentiment $c$ occasions. I said it was of importance, becauso jou mas depend up moment erery eye in Europe is fixed on the proceedings of public England, and this meeting in which the representatires of the two gathered together, will hare its comment in erery newspaper on the $C$ speak with certainty, and for this reason, that $I$ hare obserred in the press for some time past a desire to depreciate the motive power, in mili of Englund; a misconception, but one which generally prerails, and 
proportion to the business-like, soldierlike, calm was in which the qu hid before us, and in which it will be treated, will be the new ligl borne in upou those who are disposed to underralue the military country. And I say it is of importance also because you must bring mathematical foundation in military matters. Genius in a chief, zes obedience in a soldier we maj expect, but after all, the innate forces are those which are to be consulted. To illustrate this $I$ am bold te Imperial purposes, the military forces of this country put in actio spirit and genins of British war makes us as formidable a military in the world. What is the genius of British war? Expeditions fleets, maintaining a communication with the home conntry, and st by Reserves. And there is a double preparation of Reserve which referrel to in this lecture, that is to say, the Reserre of supply for $t$ ficld, or the army of operation, and the reserre of resistance, which for home purposes. With regard to the Reserre I hare a rery stron opinion as to the mẹans by which the generul subject may best be trea it is better on all occusions to aroid a confusion of supply, so to speak drawing men from one regiment into another, as has been recent extent of 4,000 men in order to make up the first army corps. It $w$ better if eacl could be prepared in its own way and in its own line, $f_{1}$ serrice. This brings me to this point, that the principle of conscr shape or another is one which we shall be compelled to adopt, and in us make it conscntancous with our spirit of aggregation in indirid called so happily the esprit de corps. Let the Army have its own i that during the Indian IIutiny, militia regiments rolunteered for for which I understand for Indin.

To show the effect of the organization of the 3rilitia Service so $t$. ready to rolunteer for foreign service, let me state this, that dur Mutiny my old soldiers came to me and said, "Sir, can't you take "scpoys?" I saic "No, I can't." Then they said, "Wliat are we t "Why, there is the recruiting sergeant, you can go and join the : "No," they said, "we will go witl our Officers and our old comrad " not go in the regulat Army." I was rers glad to hear what was sai teers. The Tolunteers are men of whom none can speak too high! their spirit, their intelligence, or for the way in which they take to have not been a colonel of Voluntecr Artillers, but I know the has hare led for the short period that they were under canras. I re: special oceasions the Essex brigate had an excessirely wearisome duty; they marched into camp for their four days' drill. The w they pitched wet, they remained wet, the weather was bad the whic course they were not prorided ritl the same means of resisting regular troops would hare been. Howerer, in spite of all these difficulties, the men did their work thoroughly well. Still a trial of great a strain for men who are not accustomed to rough serrice i therefore I las great stress upon thcir haring the opportunity of acel selres to the service of war. I was rery much struck with the $c$ shown with regard to the prorision for women and childrea. Nobor as the commanding Officers of Militia, the numbers of women and ing to the Militia Serrice. I was perfectly startled the first time I : wornen and elildren in my brigade when we wero about to learo $h$ district garrison during the Crimean War. I endearourcd to perst I could to remain at home with their families, knowing what, unc stances, garrison life must be for them.' The difficulty has to be mi and it should be met both in regard to militia regiments mored from and in regard to the regular service in the same way. At any rate this, that when the time comes, there will be one roice at least $r$ before the Gorernment the suggestions that hare been made by our

Major Wetherird, Pajmaster, R.A. : I must apologise for tres] meeting as a non-combatant, but in times like these erery Englishm doing what he can to forward suggestions. I quite agree with what 
but I should like to understand more clcarls our plan of defence in $t$ threatened inrasion. It appenrs to be generally aduitted that there are points on our shores upon which an enemy could throw a lirge force if hel in the Channel from the attack of our flect. The idea, if I am rightly info: so much to defend those rulnerable points as to collect our forces within i conrerging on these points, where they might meet an enemy that hai landing. This is a vital and inportant matter, and I consider that all should be taxed to prerent the possibility of hostile forecs discmbark shures. If there are vulnerable points upon our const, surely we might means not of merely concentrating a large force of Voluntecrs or Reser the concentration of troops takes a considerable time. Te see the dit there is on Easter Monday in conrering a few thousand Voluntecrs to point on the coast. There is also this danger to be considered, the er mike a feint to land at one particular spot, and as we were collecting or the lines of rail converging at that point, the enems might run for ano our ca:st to which our assembled forces could not be transferred by raily pussing through the small and dingerous artery of the Iletropolis; bl might take greater adrantage of the facilities which our insular positic way system might afford for concentrating on those giren points an or force of artillery. I won't say very heary guns, but large long-range $g$ of being fought on the railway metals, which might be brought to bea diembirking troops so as to present the near npproach of the enemy' check the landing of the force while our Voluntecrs and Reserves were ing. There are many other points which may be considered in connectic subject. If possible, in case of threatened inrasion, I sliould like to : blockading all the enemy's ports, and under certain combinations, our whe ssstem would be interrupted, and it is a matter worth considering how to beep up communication with our fleet in case of war. At present $I$ prorision, and I should like one simple experiment to be tried. Our shi] at a distance would hare no means of communicating with our shore seuding fast steamers between our const and the fleet; but I would sugg it would not be practirable to hare the means of sending out from certa our coast, steamers fitted with telegraphic apparatus which cou!d rus telegraph wires and anchor some thirty or forty miles or upwards fro so that when our ships wished to communieate with howe, all they wouls would be for one of their fast cruizers to run for one of these flosti ressels, which would place them in instant communication with the sh rapid information as to what was going on on the enemy's coast. That our cruizers having constantly to run into port in order to conrey info recerre instructions. As I obserre that gentlemen of the presz are presi trg to enlist them as Rescrre men : I mean in this way. No doubt. it is $\mathrm{r}$ ing to Englishmen to know exactly the details of ererything that is goir is rery desirable that the British public should be well informed as details; but I think we hare arrived at a crisis in our country's hist would be well if Englishmen generally would consider rather our natio than their own natural curiosity. It is time for the press to maintai reserre, because what is communicated to our countrymen is commu rapidly, perhaps, to that very country with which in a rery short time ourselves at war. Therefore, the imformation giren to our enemies, $a$ : friends, should bo limited. I think also that the time has arrived when and dockyards should be closed more than they are at present. TVe who the persons are who go into them to inspect them, therefore it is $d$ wo should be cautious and uso some reserration with regard to permittir to risit them. As war seems to be approaching, that we should look employés and sie that we liare no traitors among. us who miglit be $t$ ] communicating information to the enemy.

Lieutenant-Colonel EVELYN, 3rd Royal Surrey Mfilitia: I think it is in discussing matters of this kind, not to forget the distinction betwe Forces and Reserre Forces. The Reserve Forees are the First and $S$ Reserve and the Militia Reserre, but not the Militia. 
The Crainuax: Colouel Fletcher explained that in his paper.

Colonel Erecrs: I think the whole of the Auxiliars Forces should put in proper order at this crisis. We are not in danger, as the gallar who last spoke seems to imagine, of inrasion. I doubt if the Russi: idea of invading us, but they will prore a stout enemy if we attack the afraid some changes we hare lately made, certainly in the portion of $t$ Forces to which I belong, the Militia, hare not been conducire to the effi force. Regiments hare been, I fear, seriously injured by the reduction the deprivation of quarters, and by being concentrated in brigade depôt being allowed to remain at outposts. One scrious objection is the di would be if the regiments hare to be embodied in winter, in quarterin: town. It is difficult enough to billet one militia battalion in a small tc extremely difficult to billet tro, and if the Militia are wanted in the w the case in 1851 and 1855, it will be necessary to billet them, and it is $i$ billet them when concentrated trro or three battalions together in one because it happens to be the head-quarters of the brigade depôt. Varior which militiamen lare serred haro generally been misunderstood. T1 be an impression, rather general, that an $\Delta$ ct of Parliament can impose : the militiamen, whether they hare been undertaken bs his engagement instance, it was said the other day that an $\Delta$ ct of Parliament might $b_{\text {. }}$ mediately, making the Militia arailable for forcign serrice; but it forgotten that no Act of Parliament can, or at least ought not to, affec already taken. An Act of Parliament, to mako the Militia arailabl serrice during mar, ought to be passed, but still it mould not affect enlisted, at least, if it did, they would no longer be rolunteers-th pressed men. It was tried in 1855; the Militia were then serring $x$ which only bound them to be embodied in case of actual danger of inv: were wanted to replace the troops that had gone to the Crimea, anc passed empowering the Gorernment to embody them; they were embc orer England there was much discontent in the Militia, and Gorern: reconsinter their measures. I hope that no such mistake may be me the Militia are wanted for foreign serrice, there will be plenty of reg: to volunteer; but no serrice must be foreed on the men, or there will contentment and difficulty. I hope it will be remembered that, if the: take the place of the line, and are to be a sheleton foree in time of pea be depended on to march almost at a day's notice, that the staff of thi must be kept complete. There must be no such thing as the adjutane? in turns by the Captain of a regular regiment-that there should $i$ Adjutant, but an Officer of a regular regiment acting as Adjutant. This Adjutant for a Militia regiment should not be restricted to the ten $\mathrm{Ca}$ linked line battalion, of whom the tro or threo seniors are too near the to hold a five Jears' appointment. The best of the other Captains do leave their own companies, and probably the onls one who can be indu a militia adjutancy is one who wants to marry, or aroid foreign serrice similar reason. That is an arrangement that docs not work at all. $\mathrm{Tr}$ other things that were to be carried out as proposed by the Militi such as these; that a militia regiment should eren be dcprired of major, of its quartermaster sergeant, of its orderly-room clerk, of it: clerk, in fact, of erery single thing that makes a battalion a bati regiment of Militia was to be made a mere unorganized band of recru teased into joining the regular ArmJ as quickly 23 possible. That w much like killing the goose that has the golden eggs. If you want stream of recruits from the Militia, Jou must keep up the militia regir destroy them, and the staff should be alrags complete, and lodged in $\mathrm{g}$ under the constant superrision of the Adjutant. Under present circ: better plan could be adopted than that of giving up some of the num depôt establishments to the militia battalions.

The Volunteers are a most admirable force, and, for my own spared myself neither trouble or espense in trying to promote th Still, we must remember that in the time of the Peninsular war tl. 
fell a great deal into disuse after the establishment of the local militia-a force of which one neter hears now, and a force which probably many gentlemen in the room never heard of. It was a force organized in the different parishes and dirilled on the rillage greens, and formed a fer times in the course of the jear into a battalion. It was found, in many respects, a more conrenient forco than the Folunteers, though the Voluntecrs had thcir place and were most admimble in many Fopects. But what on earth can induce those young gentlemen in the Volunteers to rish, under present circumstances, to serre abroad as prirate soldiers I cannot quite understand ! However, if thes like it well and good, but I am afraid, if thes quive to work with the pas and allowances of prirate soldiers, and no others, they would not like it rery much. If they expect double and treble pay and pensions when thes got home, \&c., they will be rery expensire, and perhaps hardly worth their money. There is one thing I think would add enormously to the effeiency of the Militia. The system of deferred pay has done a great deal of good in the Army, though eome of the provisions under which it has been introduced are not, in my opinion, rery judicious. I have some right to speak on the subject of deferred pay, for I beliere, if it had not been for a letter of mine that appeared in the Times, in October, 1873, the term "deferred pay" rould not have been applied to this day, with reference to the pay of the soldier, and I was eomewhit amused, a jear or two stter my letter appeared in the Times, to see a long discussion, whether Captain Trench or Archdcacon Wright, or somebody else, was the first to make the sugges. tion. Howerer, I held my peace. I think a modification of deferred pay might be introduced into the Militia, and would stop desertion to a very great extent, as the men get no pay, except when up for training, it would necessarily be a deferred bounty. I quite agree that, in time of war, a system of ballot for the Militia should be re-introduced. But if it is, I do think a man who is balloted for and serres in the Militia fire or six years, ought not to be turned adrift, without a farthing in his pocket, at the end of that time; and if the country gave erery man who did good serrice during his period in the Militia, a $5 l$. note, it would not be a bit too much for him to go back to his friends with, and it would make the militia serrice far more popular than it is, and would prerent the great militia riots which occurred. in the late war in consequence of the Ballot Act being put in force. That Ballot tot was carried out with great difficulty, and was attended by sereral great riots. It mas found very difficult to carry out a mcasure of that sort in England, and doubtless nowadays the diffeulty would be increased.

Major WetrenHED: I should just liko to explain that in what I stated I did not for a moment intend to express the belief that Russia would invade Fngland.

General Sir Wildiax CodrixgtoN : I do not know whether the lecturer referred to the conscription as a necessary part of the Reserve, or any part of the system of Fngland, but Lord Wareney did so refer to it, and possibly it might go fortard that it was the feeling of a great number of Officers, that it is necessary to have conscription in England. Now, as ereryone is entitled to his opinion, I must own my opinion is decidedly against it, except in case of necessity balloting for Militia for home defence. Conscription for general Army eervice is contrary to the feeling of England. Not only is it contrary to the feeling of Fngland as a matter of oppression, but it is an extreme oppression in France, in Prussia, and in Russia, where there can be no question about it, and as such, it is contrary to the usual habits and spirit of liberty and fecling in England. On the other hand, I do not beliere that there is any more expensive system than this one of conseription. Cheap to the Gorernment, but not nominally cheap for, general national interests, or for the lives of the men exposed to it ; because $I$ beliere there is rery little doubt that the hospital and other arrangements in a conscription-country in war hare not the same attention paid to them as in England, where the Army is a rolunteer army. One main point, howerer, is that it is a rery expensire ssstem nationally. You take away from all classes of society the best members for national improrement, its able-bodied and those of full age; and you force them into the Serrice not only in nar but in peace. They aro taken and not able to carry on their own business, or to marry for so many years; I think it is ten, and this in the rery prime of a man's life. Therefore $\bar{I}$ hope it will not be considered as a necessity for England that conseription should take place for the Arny. 
Lord WArExeY : I lope I gurded myself in what I said; in 1 sure I did so guard myself in the first part of my obserrations. It principle of conscription we must come; I believe we must come to 1 gencral obligation for serrice, and I think I guarded myself by sayini by the old form of the ballot, which in its original form takes erery $n$ other manifestation of the principle that no man is to be held exempt for home defence, I should wish it to be felt that there is always : serve for home defence.

Colonel ALCock: I am perfectly conrinced that the great strengt this country arises from the sfstem of roluntary ecrice, and that $t$ ness of foreign countries, although it may appear to be otherwise, ari: tory serrices, and the reason is rery obrious. It is this, that the obligatory service is so great that the time will ultimately arrire r will resist it, and it must be felt at this moment in Russia; in $f$ by the public prints, that in that country unfortunate men are: homes and marched off immediately to the war without haring : of taking leave of their friends. The conclusion I come to wil the discontent so caused, is one in which I am supported by, I belie great philosopher; for it was the opinion of Auguste Comte many : he said that the people would ultimately rebel against the tyranny serrice. There is in continental countries another source of weak with this which does not affect us, and the freedom from which a? must add enormously to the stability and power of Englaud, and $t$ of the secret societies. It is perfectly well known that there is a mi: dynamite under many kingdoms, and especially under Russia, an ready at any moment to explode. I will say no more upon this sul adhere to my opinion. 1

Lieutenant G. II. IIoste, Ciril Serrice Rifles : A gallant Officer, w' opposite side of the theatre (Colonel Erelrn) drew attention to th lecture which dealt with the question of the employment of Volun service. As is probably known to most of this assembly, this que recently much rentilated, and the most opposite riews are expressed my own part, speaking not for a class but as an indiridual Volun that I cordially agree witli the arguments adranced and the conclusios Colonel Fleteher. It was said by Colonel Eveln that Voluntecrs sc: time of war would not care for the life. Now, Sir, I do not:supposc goes to war with the idea of enjoying himself, but rather with th: duts; and I an conrinced that, in the discharge eren of the ar actire scrrice, Volunteers would not shrink from encountering Equally do I lope that there are many who, in such an emergen described, would be willing to sit rery loosely to their ciril professic gire up those professions and their prospects altogether, and who wor themscles in a special brigade or dirision fos serrice abroad. I de Tolunteer Force onght to consider itself greatly indebted to Color haring drawn out a definite echeme by which the opportunity of se promised to it, and I trust that, if the need arises, that opportunity w

Licut.-Colonel Busubr, Rifle Voluntecrs: The gentleman who has partly taken out of my mouth what I was going to say. I wanted to result to your lecture. I do so with great difficlence, because two letter from Lord Elcho and the Honourable Charles Lindsay speaking aga being employed for foreign serrice. If war should unhappily break oul

1 As political subjects are not allowed in the discussions at th thought myself called upon to stop, but I beliere that without infrir rules, and after haring alluded to the reaction in other countries ac wars, in which the assailant trusts to the porrer of compulsory enrri might hare added that, when the great amount of physical force wh by that means is compared with the smaller figures shown by the ro we must likewise compare the want or the amount of inherent mol cach of these systems will respectively promote.-T. S. L. A. 
erery man that can come forward will be required. I think it would $t$ excellent thing if the Gorernment opened a small office somewhere bourhood of Charing Cross to take the names of men who would foreign serrice. I will confidently assert that out of the 100,000 yo soon get up a brigade of say 3,000 men for active serrice abroad, officered in a very short time, and might be fed from that very Yo which we keep in England as a Reserre. There are thousands and soung men who pay no taxes to the State, living with their families, $d$ who might rery well go forward and show that the middle class wor ready as the upper and the lower classes to face danger and death. I body of men might be a beginning, and might be fed from the Volunter ill erents, I am quite sure if warkere forced upon this country you $\mathrm{m}$ that bods a small beginning, saj 3,000 drilled men, from whom unc such as I see before me, fou would get, not only good, but desperate sc

Mr. Lowe (Queen's Westminsters) here mado some remarks regardi colours into action, and regarding the colour of the fighting dress of $\mathrm{tl}$ rot being à propos of the subject of the lecture they are not giren.

Colonel Fletcher: There are rery few points that $I$ liare to an regard to what Major Wetherhed said, my lecture was upon the $L$ Forces, not the Naral Reserre Force. I think the Naval Reserve Force a most excellent topic for a lecture. I agree with Sir William Codring great thing is to aroid a ballot if we possibly cam, and all that $I$ hint ballot for the Militia for home defence, which I thought we might hare recourse to. The object of $\mathrm{my}$ lecture was to show how unirersal if it is to be aroided, is only to be aroided by extending the channels of and increasing the means by which an army may bo raised. I must tha? and Colonel Busbby rers much for their remarks with regurd to the Tol which are very raluable as coming from Officers who hare had so $v$ perience of that force. I am rers glad to find that my opinions cuincid

The Crairyax : I think I may renture in one roord to take the meeting with regard to the raluable paper which has been read, and $t$ friend Colonel Fletcher for it. I say our friend because he is alike the Army and of the Auxiliary Forecs. Sereral burning questions ha cussed, and foremost is that of conscription. I must eay I am in Englishman to depend more upon the spirit of the people for kee sinews of war. But in an emergency the ballot may be resorted to up the Mfilitia, and if Tre lare to do that it rould not be at rariar. F.nglish institutions; it is not long ago indeed since the ballot was th That, howerer, would only be a very partial operation, and very diff, general conscription, which would greatly injure commercial interest was made by our gallant friend, in the carly part of his lecture, to tl of employing our Indian troops, and I think that is a very important us to consider. I hate heard it said more than once in this country lare war with Russia we might reckon upon India to furnish a continge troops. Now, I have serred sereral times in India, and lately command there, and $I$ am bound to say that in such a war $I$ would go into act: greatest confidence at the head of sepoy troops, especially the Sikhs a But there is one point that must be rectified before they can be brougl to join in a Russion War, and that is in the tactical organization of th The European Oficers are too few. They are well trained, well educat. Officers, but they aro too fer, and the tactical duties assigned to them a faulty. 'There are only seren Offecrs to a regiment of infantry, and mounted. At $\mathrm{my}$ first inspection of a regiment, I asked their tactical distribution in field morements. They knew of none, except to super the regiment marched past, six Officers followed the last company, havin command whaterer. The companies are commanded by natives very we] but they are incapable of tactical knowledge.

Upon one occasion, at a ficld day, I purposely drove a brigade through rough ground, but such as infantry might hare to work through in actio: ras not a single European Officer to be scen with one of the regiments; bei

50L. XxII. 
back, they were all choked off behind. Therefore, although do be a great thing to employ nativo troops in a European war, still il very different tactical arrangements to thoso adopted at present. our Tolunteers joining the Army, which was another of the subject: exists much difference of opinion; our military s5stem is compos branches serving under the provisions of their respectire Acts, the $r$ Militia, and tho Volunteers. Then there are tro subsidiary Acts $\nabla$ Army and Militia Reserres. Now four of theso admit of serrieo Volunteer Act keeps the Volunteer at home; be is enrolled under for the purposes of home defence. Nerertheless, it is only natural should rith the whole country be imbued with n clesire to maintaj England abroad as well as its defence at home. The only question best be accomplished. It has been propozed to organize battalions, of those Volunteers, who desired to serre abroad; and $I$ dare say $t$ would be rery glad on an emergency to authorize such battalion Voluntecrs under sclected Officers, to be curolled for that purpos would belong to the Army; they would not be any longer Volur Act of 1863. Speaking as an Army Officer, I would welcome in t1 are become almost seasoned soldiers by this time. But as a Vo should sny, "God speed you as Tolunteers to the Army, but no 1 " under the Act." IIy gallant friend mentioned also the adrisabilit instruction in the erent of war, and I entirely agree with him; it absolutely necessary. But instead of selecting the sites of those $\mathrm{ct}$ tion in strategical localities, I would be inclined to hrve them rat homcs, and within easy reach of railways, in fact near railway the men should be able to follow to a certain extent their own pu: same time receire instruction in large bodies to fit them for their d I hare nothing more with which to detain you, but request that 5 me in thanking Colonel Fletcher for his rery able paper. 